\title{
Formulation, Development and Evaluation of Bilayer Tablet of Flurbiprofen
}

\author{
Nitin A Gaikwad*, Indrjeet V Mane, Manohar D Kengar, Ranjeet S Jadhav \\ Department of Pharmaceutics, Rajarambapu College of Pharmacy, Kasegaon, Maharashtra, India \\ Corresponding Author E-mail :- nitingaikwad2018@gmail.com
}

\begin{abstract}
In the Study of Formulation of Bilayer Tablet of Flurbiprofen the Following Materials Using sodium starch glycolate as immediate release and HPMC K15 in different ratios as release retardant materials using a wet granulation method. All tablets exhibited good physical properties with Respect to appearance, content uniformity, hardness, weight variation and Invitro dissolution data show at increasing proportions Of sodium starch glycolate for immediate release whereas HPMC K15sustaineddrugreleaserate. The bilayer tablets showed an initial release of drug In about $1 \mathrm{hr}$, then sustaining the release for $12 \mathrm{~h}$, The kinetic analysis of dissolution data showed that release was observe din these tablets. When data was fitted to the Higuchi model. Bilayer tablets of flurbiprofen can be successfully formulated Using sodium starch glycolate and HPMC K15 in different ratios as release retardant materials employing a wet granulation method.
\end{abstract}

Keywords : Sodium Starch Glycolate, HPMC K15, Wet Granulation Method.

\section{INTRODUCTION}

Bilayer tablet is suitable for sequential release of two drugs in combination, separate two incompatible substances and also for sustained release tablet in which one layer is immediate release as initial dose and second layer is maintenance dose. Bilayer tablets have been developed to achieve controlled delivery of different drugs with pre defined release profiles. In the last decade interest in developing a combination of two or more API's in a single dosage form has increased in the pharmaceutical industry, promoting patient convenience and compliance. Several pharmaceutical companies are presently developing bi-layer tablets, for a variety of reasons patent extension, therapeutic, marketing to name a few. ${ }^{1}$ Incertin conditions drug treatment may be advantageous to be delivered in a biphasic manner rather than a single phase extended release preparation. In the first phase of drug release, the immediate release dose fraction (also called loadingdose) reaches a therapeutic drug level in the blood plasma quickly after administration, while the second extended release phase (called the maintenance- dose) provides the dose fraction, required to maintain an effective the rapeutic level for a prolonged period. Examples of such systems can be founds bilayer tablets, drug layered matrices or combinations of immediate and extended release multi particulates.

\section{METHODS AND MATERIAL}

\section{Chemicals:}

Flurbiprofen were purchased from aarti Pharmaceuticals Pvt. Ltd. Mumbaisodium starch glycolate, (Research grade were purchased from loba chem.)HPMC K15 purchased from color on lab, Starch, Pvp-k-30, Microcrystalline Cellulose, Lactose 
fraction, required to Talcum and Magnesium Stearate.

\begin{tabular}{|c|c|c|c|c|c|c|}
\hline & \multicolumn{5}{|c|}{ Batches } \\
\hline Ingredients & $\begin{array}{c}\text { IR } \\
\mathbf{1}\end{array}$ & IR 2 & IR 3 & IR 4 & IR 5 & IR 6 \\
\hline Flurbiprofen & 50 & 50 & 50 & 50 & 50 & 50 \\
\hline $\begin{array}{c}\text { Crosscarmell } \\
\text { ose }\end{array}$ & 2 & 6 & 10 & --- & --- & --- \\
\hline $\begin{array}{c}\text { Sodium } \\
\text { Starch } \\
\text { Glycolate }\end{array}$ & --- & --- & --- & 2 & 6 & 10 \\
\hline $\begin{array}{c}\text { Lactose } \\
\text { Pregelitinised } \\
\text { starch } \\
\text { solution }\end{array}$ & q.s & q.s & q.s & q.s & q.s & q.s \\
\hline $\begin{array}{c}\text { Magnesium } \\
\text { stearate }\end{array}$ & q.s & q.s & q.s & q.s & q.s & q.s \\
\hline Talc & q.s & q.s & q.s & q.s & q.s & q.s \\
\hline $\begin{array}{c}\text { Total weight } \\
\text { Tog } \\
0\end{array}$ & 200 & 200 & 200 & 200 & 200 \\
\hline
\end{tabular}

\section{Formulation of Preliminary batches of FB Immediate Release layer (IR1-IR6)}

The composition of preliminary batches of immediate release layer is given in the following table. The ingredients viz. flurbiprofen, croscarmellose / sodium starch glycolate and lactose monohydrate were mixed in mortar and pestle in geometrical manner. Aqueous wet granulation method was used for the preparation of IR layer. Pregelitinised starch was used as the binder. 5\% starch paste was prepared using water. This paste was added in the above mixture of ingredients in sufficient quantity to obtain wet mass. This wet mass was then passed through sieve no. 16 to obtain the granules. These granules were then dried at $60^{\circ} \mathrm{C}$. Dried granules were then passed through sieve no 40 to gain fines. The granules were lubricated with talc and magnesium stearate. Calculated amount of fines were then added to granules and mixed. The granules were punched on single punch tablet press tablet machine with final weight of tablet as $200 \mathrm{mg}$.
Table 2 : composition of preliminary trial Batches.

\begin{tabular}{|c|c|c|c|c|c|c|}
\hline & \multicolumn{5}{|c|}{ Batches } \\
\hline $\begin{array}{c}\text { Ingredien } \\
\text { ts }\end{array}$ & SR1 & $\begin{array}{c}\text { SR } \\
\mathbf{2}\end{array}$ & SR3 & SR4 & SR5 & SR6 \\
\hline $\begin{array}{c}\text { Flurbipro } \\
\text { fen }\end{array}$ & 50 & 50 & 50 & 50 & 50 & 50 \\
\hline $\begin{array}{c}\text { HPMC } \\
\text { K15 }\end{array}$ & 2 & 6 & 10 & --- & --- & --- \\
\hline $\begin{array}{c}\text { Xanthum } \\
\text { Gum }\end{array}$ & 148 & $\begin{array}{c}14 \\
4\end{array}$ & 140 & 148 & 144 & 140 \\
\hline $\begin{array}{c}\text { MCC } \\
\text { PVP K30 } \\
\text { solution }\end{array}$ & q.s & q.s & q.s & q.s & q.s & q.s \\
\hline $\begin{array}{c}\text { Magnesi } \\
\text { um } \\
\text { stearate }\end{array}$ & q.s & q.s & q.s & q.s & q.s & q.s \\
\hline Talc & q.s & q.s & q.s & q.s & q.s & q.s \\
\hline $\begin{array}{c}\text { Total } \\
\text { weight }\end{array}$ & 200 & 20 & 200 & 200 & 200 & 200 \\
\hline
\end{tabular}

\section{Fourier transformed infrared (FTIR) spectroscopy}

The $\mathrm{KBr}$ dispersion pellet of the given sample of Flurbiprofen, sodium starch glycolate and HPMC $\mathrm{K} 15 \mathrm{M}$ were prepared and scanning was done by using Shimadzu IRSpectrophotometer at SAIF, Chandigarh, India. The spectrum obtained has wellresolved peaks, which ascertained the purity of the sample of all three drugs. The sampleIR spectrum was interpreted \& matched with reference IR spectra, which infers that thecompound contains all the peaks to be obtained as authentic sample of drugs.

\section{UV Spectroscopy:}

Accurately weighed drug $(100 \mathrm{mg})$ was transferred to a $100 \mathrm{ml}$ volumetric flaskand dissolved in and diluted to $100 \mathrm{ml}$ with, water, 6.8 phosphate bufferseparately. Final standard stock solution of $100 \mu \mathrm{g} / \mathrm{ml}$ was prepared by diluting $10 \mathrm{ml}$ ofthe above solution to $100 \mathrm{ml}$ with respective solutions. The standard stock solutions ofFlurbiprofen scanned in the range of 200 to $400 \mathrm{~nm}$ against, water, 6.8phosphate buffer. Maximum absorbance was obtained at $247 \mathrm{~nm}$ in all solutions. 
Calibration curves were plotted over a concentration range of $2-20 \mu \mathrm{g} / \mathrm{ml}$. accurately measured standard stock solutions $(0.2,0.4,0.6,0.8,1.0,1.2,1.4,1.6,1.8$, $2.0 \mathrm{ml}$ ) were transferred to a separate series of $10 \mathrm{ml}$ volumetric flasks. The volume was adjusted to the mark with $0.1 \mathrm{~N}$ HCL, water, 6.8 phosphates buffer separately and mixed. The absorbance of each solution was measured at $247 \mathrm{~nm}$ against water, 6.8 phosphate buffer as a blank respectively. Calibration curves were constructed by plotting absorbance versus concentrations at $247 \mathrm{~nm}$ wavelength. Each reading was an average of three determinations.

\section{In-vitro Release Studies:}

The in-vitro dissolution study of all the batches Flurbiprofen was carried out using USP II (Paddle) dissolution apparatus. The test was performed using $900 \mathrm{ml}$ of $\mathrm{pH} 6.8$ phosphate buffer at $50 \mathrm{rpm}$ and $37 \pm 0.5{ }^{\circ} \mathrm{C}$. The samples $(5 \mathrm{ml})$ of the solution were withdrawn at each specified time intervals and the sink condition was maintained by transferring $5 \mathrm{ml}$ of fresh dissolution media each time of the sample withdrawal. The samples were diluted with same media if needed then analyzed at $247 \mathrm{~nm}$ using UVVisible spectrophotometer.

\section{Release Kinetics:}

To study the mechanism of drug release from the sustained release matrix tablet, the in vitro drug release data were fitted to various kinetic models like zero order as cumulative amount of drug release $\mathrm{v} / \mathrm{s}$ time, First order as log cumulative $\%$ of drugremaining v/s time, Hixson-Crowell, Higuchi as cumulative $\%$ of drug release $\mathrm{v} / \mathrm{s}$ square root of time and K-Peppas equation and coefficient of correlation ( $r$ ) values were calculated for linear curves by regression analysis of the above plot.This study was done by using microsoft excel. These models used to explain drug release mechanism of the tablet release.

\section{RESULTS AND DISCUSSION}

\section{DRUGEXCIPIENTSCOMPATIBILITY STUDY}

IR study of drug:

FTIR spectra of flurbiprofen and showed the same absorption pattern as the combination of drugs and excipients of formulations.

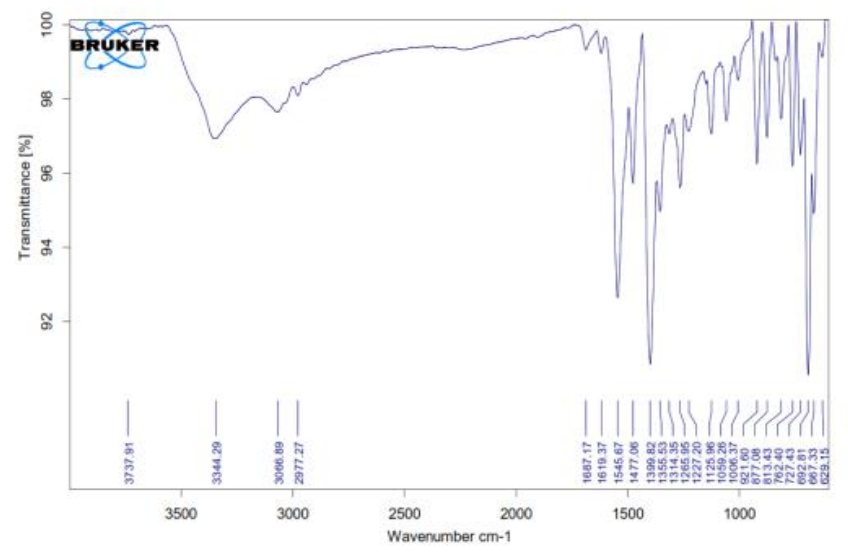

Fig.1 : IR of Flurbiprofen

Table 3. IR Interpretation of Flurbiprofen

\begin{tabular}{|c|c|c|c|}
\hline Sr.no & $\begin{array}{c}\text { Funtional } \\
\text { group }\end{array}$ & $\begin{array}{c}\text { Reported } \\
\text { range }\end{array}$ & $\begin{array}{c}\text { Observed } \\
\text { range }\end{array}$ \\
\hline 1 & $\begin{array}{c}\mathrm{C}-\mathrm{F} \text { (fluorin } \\
\text { group) }\end{array}$ & $1000-1400$ & 1125.96 \\
\hline 2. & $-\mathrm{OH}$ ( acid) & $3300-3600$ & 3344.25 \\
\hline 3. & $-\mathrm{CO}$ (acid) & $1705-1720$ & 1687.17 \\
\hline 4. & $\begin{array}{c}\mathrm{CH}(\text { methyl } \\
\text { group) }\end{array}$ & $1450-1375$ & 1355.53 \\
\hline 5. & $\mathrm{C}=\mathrm{C}$ & $1500-1600$ & 1545.67 \\
\hline
\end{tabular}

Preformulation and Post formulation Results:

All pre formulation parameters were applied. Bulk density and tapped density are two of the most important studies to be done before the development of formulation. Bulk density, angle of repose, compressibility index, hausner's ratio, moisture content and tapped density were checked by adopting the standard methods as described in USP. Results are shown in. These values were in acceptable range. 
Table 4. Precompression parameters of FB IR layer (IR1-IR6)

\begin{tabular}{|c|c|c|c|c|c|c|}
\hline parameters & IR1 & IR2 & IR3 & IR4 & IR5 & IR6 \\
\hline $\begin{array}{c}\text { Weight } \\
\text { variation (mg) }\end{array}$ & $\begin{array}{c}198 \pm 1 . \\
2\end{array}$ & $201 \pm 1.5$ & $199 \pm 1.3$ & $198 \pm 0.8$ & $\begin{array}{c}199 \pm 0 . \\
8\end{array}$ & $200 \pm 0.9$ \\
\hline $\begin{array}{c}\text { Hardness } \\
\left(\mathrm{kg} / \mathrm{cm}^{2}\right)\end{array}$ & $\begin{array}{c}5.1 \pm 0 . \\
2\end{array}$ & $4.9 \pm 0.1$ & $5.2 \pm 0.3$ & $5.2 \pm 0.1$ & $5.2 \pm 0.1$ & $5.0 \pm 0.3$ \\
\hline$\%$ Drug content & 98.4 & 99.1 & 97.5 & 99.4 & 99.4 & 98.6 \\
\hline $\begin{array}{c}\text { Disintegration } \\
\text { time (min) }\end{array}$ & $\begin{array}{c}8.42 \pm 0 \\
.42\end{array}$ & $\begin{array}{c}6.22 \pm 0 . \\
28\end{array}$ & $\begin{array}{c}3.41 \pm 0.4 \\
9\end{array}$ & $6.48 \pm 0.35$ & $\begin{array}{c}6.48 \pm 0 . \\
35\end{array}$ & $2.58 \pm 0.36$ \\
\hline
\end{tabular}

Table 5. Post-compression study of FB IR layer (IR1-IR6)

\begin{tabular}{|c|c|c|c|c|c|c|}
\hline $\begin{array}{c}\text { Time } \\
(\mathrm{min})\end{array}$ & IR1 & IR2 & IR3 & IR4 & IR5 & IR6 \\
\hline $\mathbf{2}$ & $11.81 \pm 0.81$ & $12.6 \pm 0.51$ & $14.17 \pm 0.25$ & $15.86 \pm 0.35$ & $18.11 \pm 0.85$ & $16.98 \pm 0.12$ \\
\hline $\mathbf{5}$ & $35.43 \pm 0.63$ & $40.61 \pm 0.70$ & $44.88 \pm 0.52$ & $46.35 \pm 0.58$ & $44.7 \pm 0.49$ & $44.1 \pm 0.42$ \\
\hline 10 & $45.11 \pm 0.97$ & $45.22 \pm 0.92$ & $58.27 \pm 0.41$ & $60.07 \pm 0.42$ & $63.11 \pm 0.41$ & $62.32 \pm 0.98$ \\
\hline 15 & $57.93 \pm 0.48$ & $60.75 \pm 1.1$ & $69.07 \pm 0.52$ & $67.38 \pm 0.47$ & $75.48 \pm 0.27$ & $76.61 \pm 0.73$ \\
\hline 30 & $66.48 \pm 0.72$ & $68.73 \pm 0.48$ & $78.63 \pm 0.85$ & $78.9 \pm 0.28$ & $87.52 \pm 0.95$ & $85.6 \pm 0.43$ \\
\hline 45 & $76.61 \pm 0.61$ & $78.52 \pm 0.57$ & $80.32 \pm 0.25$ & $87.86 \pm 0.35$ & $90.45 \pm 0.71$ & $89.1 \pm 0.49$ \\
\hline 60 & $83.36 \pm 0.90$ & $86.4 \pm 0.85$ & $88.98 \pm 0.75$ & $95.73 \pm 0.84$ & $98.55 \pm 0.75$ & $97.9 \pm 19$ \\
\hline
\end{tabular}

Table 6. \% Cumulative drug release of preliminary batches of FB IR layer (IR1-IR6)

\begin{tabular}{|c|c|c|c|c|c|c|}
\hline Parameters & SR1 & SR2 & SR3 & SR4 & SR5 & SR6 \\
\hline Angle of Repose & 30.45 & 29.45 & 28.44 & 28.00 & 32.25 & 27.65 \\
\hline $\begin{array}{c}\text { Bulk density } \\
\text { (gm/ml) }\end{array}$ & 0.43 & 0.42 & 0.41 & 0.40 & 0.49 & 0.42 \\
\hline $\begin{array}{c}\text { Tapped density } \\
\text { (gm/ml) }\end{array}$ & 0.50 & 0.48 & 0.47 & 0.46 & 0.57 & 0.45 \\
\hline Carr's & 12.4 & 12.11 & 12.60 & 12.26 & 12.71 & 12.25 \\
\hline Hausner & 1.14 & 1.148 & 1.144 & 1.14 & 1.150 & 1.139 \\
\hline
\end{tabular}

Table 7. Pre-compressional parameters of preliminary batches of FB SR layer. 


\begin{tabular}{|l|c|c|c|c|c|c|}
\hline parameters & SR1 & SR2 & SR3 & SR4 & SR5 & SR6 \\
\hline $\begin{array}{l}\text { Weight } \\
\text { variation (mg) }\end{array}$ & $198 \pm 1.2$ & $197 \pm 1.5$ & $199 \pm 1.3$ & $198 \pm 0.8$ & $\begin{array}{c}200 \pm 1 . \\
5\end{array}$ & $200 \pm 0.9$ \\
\hline $\begin{array}{l}\text { Hardness } \\
\left(\mathrm{kg} / \mathrm{cm}^{2}\right)\end{array}$ & $6 \pm 0.2$ & $6.5 \pm 0.1$ & $5.5 \pm 0.3$ & $6.2 \pm 0.1$ & $6 \pm 0.2$ & $5.0 \pm 0.3$ \\
\hline$\%$ Drug content & 97.4 & 98.1 & 98.5 & 98.4 & 98.9 & 96.6 \\
\hline $\begin{array}{l}\text { Disintegration } \\
\text { time (min) }\end{array}$ & $\begin{array}{c}2.42 \pm 0.4 \\
2\end{array}$ & $\begin{array}{c}6.22 \pm 0.2 \\
8\end{array}$ & $\begin{array}{c}3.41 \pm 0.4 \\
9\end{array}$ & $\begin{array}{c}6.48 \pm 0.3 \\
5\end{array}$ & $\begin{array}{c}6.12 \pm 0 . \\
24\end{array}$ & $\begin{array}{c}8.58 \pm 0.3 \\
6\end{array}$ \\
\hline
\end{tabular}

Table 8. Post-compressional parameters preliminary batches of FB SR layer (SR1-SR6).

\begin{tabular}{|c|c|c|c|c|c|c|}
\hline $\begin{array}{l}\text { Time } \\
\text { (hrs.) }\end{array}$ & SR1 & SR2 & SR3 & SR4 & SR5 & SR6 \\
\hline 0.5 & $4.05 \pm 0.81$ & $5.4 \pm 0.42$ & $7.6 \pm 0.84$ & $15.4 \pm 0.25$ & $19.23 \pm 0.45$ & $16.58 \pm 0.21$ \\
\hline 1 & $7.9 \pm 0.72$ & $9.9 \pm 0.36$ & $11.8 \pm 0.61$ & $23.3 \pm 0.24$ & $32.06 \pm 0.72$ & $24.97 \pm 0.42$ \\
\hline 2 & $12.37 \pm 0.41$ & $13.16 \pm 0.52$ & $16.65 \pm 0.67$ & $35.4 \pm 0.74$ & $39.03 \pm 0.4$ & $30.48 \pm 0.18$ \\
\hline 3 & $22.9 \pm 0.32$ & $24.07 \pm 0.35$ & $32.06 \pm 0.72$ & $43.5 \pm 0.41$ & $48.48 \pm 0.21$ & $45.56 \pm 0.27$ \\
\hline 4 & $30.15 \pm 0.65$ & $31.6 \pm 0.14$ & $37.34 \pm 0.41$ & $45.4 \pm 0.12$ & $56.02 \pm 0.34$ & $51.32 \pm 0.45$ \\
\hline 5 & $35.43 \pm 0.48$ & $36.9 \pm 0.28$ & $46.46 \pm 0.52$ & $55.4 \pm 0.46$ & $62.7 \pm 0.32$ & $59.28 \pm 0.38$ \\
\hline 6 & $43.98 \pm 0.71$ & $46.9 \pm 0.41$ & $48.03 \pm 0.24$ & $65.4 \pm 0.52$ & $70.65 \pm 0.41$ & $66.48 \pm 0.11$ \\
\hline 7 & $45.56 \pm 0.52$ & $55.8 \pm 0.37$ & $57.82 \pm 0.41$ & $76.1 \pm 0.37$ & $79.98 \pm 0.28$ & $76.95 \pm 0.32$ \\
\hline 8 & $56.7 \pm 0.25$ & $57.03 \pm 0.42$ & $61.65 \pm 0.52$ & $78.6 \pm 0.56$ & $87.86 \pm 0.37$ & $87.3 \pm .22$ \\
\hline 9 & $61.65 \pm 0.74$ & $62.77 \pm 0.48$ & $69.18 \pm 0.48$ & $87.4 \pm 0.42$ & $92.02 \pm 0.16$ & $90.33 \pm 0.37$ \\
\hline 10 & $65.92 \pm 0.36$ & $70.65 \pm 0.52$ & $75.48 \pm 0.32$ & $93.4 \pm 0.43$ & $97.65 \pm 0.24$ & $95.28 \pm 0.32$ \\
\hline
\end{tabular}

Cumulative drug release of preliminary batches of FB SR layer (SR1-SR6)

\section{CONCLUSION}

In the present work, the incorporation of Flurbiprofen, an anti-inflammatory agent was performed in inert HPMC K 15 and Sodium Starch Glycolate. where sodium starch glycolate is used as super disintegrating agent and HPMC $\mathrm{K}$ 15and polymer in different concentration is used to achieve sustained release kinetic for drug. There was no chemical interaction between the drug and polymers as inferred primarily from DSC and FTIR .Thus by Hydroxyl propyl methyl cellulose proved useful as arate controlling polymer to produce a controlled release formulation of Flurbiprofen using the dissolution controlled mechanism. The prepared optimized bi-layer tablet formulation of flurbiprofen was stable. Hence, this optimized bi-layer dosage form could be a potential formulation for delivery of drugs from a single dosage form could be potential formulation for delivery of drug from single dosage from could be improve patient compliance and give better disease management. 


\section{REFERENCES}

[1]. Mukho padhyay S, Goswami L, Satheesh Madhav Nv, U padhyaya K. Formulation and evaluation of floating bioadhesive tablets of Ciprofloxacin hydrochloride by direct compression technique. Int J Pharm and Pharm Sci. 2010; 2(3): 113-15.

[2]. Derle D, Joshi O, Pawar A, Patel J, Jagadale A. Formulation and evaluation of buccoadhesive bi-layer tablet of propranolol hydrochloride. Int J Pharm and Pharm Sci.2009; 1(1): 206-12.

[3]. Allen, Loydv: Ansel's pharmaceutical dosage form and drug delivery systems by loyd V. allen edition 2014.

[4]. USP37NF32 United states pharmacopoeia: United States pharmacopial convention 2014.

[5]. Banu H and Sahariar M R. Formulation development of bi-layer acetaminophen tablets for extended drug release. JChem Pharm Res.2011; 3(6):348-360.

[6]. Solanki P D. Formulation evaluation and optimization of bilayer floating tablet of repaglinide and glipizide. Inter J Pharm Rese Schoc.2012; 1(3):123-134.

[7]. Sadhana R S and Vidya M M. Development and evaluation of bilayer floating tablets of diltiazem hcl.Inter J Pharm Pharm Scien.2014; 6(2):62-65.

[8]. Sharma V, Nagpal M, Jain U K, Mangotia A and Kumar R. Anti diabetic drug and combination therapy ARPB,2013;3(2):389-394.

[9]. Ali S H and Reddy B R. Formulation and evaluation of bilayer tablet of atorvastatin and pioglitazone form etabolic disorder. IAJPS. 2014; 1(6):448-455.

[10]. Banu H, Mostafa R, Muhammad S, Irin D And Ashraful S; Formulation Development Of BiLayer Acetaminophen Tablets For Extended Drug Release; J. Chem. Pharm. Res;2011;3(6);348-360.
[11]. Bhandari A, Bilayer tablet or a solid drug delivery system and challenges in the formulation: Anre view; IJPRD; 2011; vol. 4(03); may-2010 29-44.

[12]. ChienY.W. Novel drug delivery systems; 2nd Ed.; Marcel DekkerInc: NewYork: 1992; 13940.

[13]. .Gudsoorkar V. R, Rambhau D.; Sustained release of drugs; The Eastern Pharmacist, 1993; 36(429); 17-22.

[14]. Hoffman A.; Pharmacodynamic aspects of sustained release preparations; Adv Drug Del Rev; 1998; 33: 185-99.

[15]. Hui H. W, Robinson J. R, Lee V. H. L.; Design and fabrication of oral controlled release drug delivery systems. In: Robinson JR, Lee V, editors. Controlled drug delivery fundamentals and applications; 2nd Ed.; Marcel Dekker: New York: Inc; 2005; 373-4.

[16]. Jain N. K.; Controlled and novel drug delivery; 1stEd. CBS Publishers; New Delhi; 2002; 275318.

[17]. Pujara N; Bilayer tablet - Anemerg in gtrend; IJPRD; 2011; vol.4 (04); june-2012; 102-111.

Cite this article as :

Nitin A Gaikwad, Indrjeet V Mane, Manohar D Kengar, Ranjeet $\mathrm{S}$ Jadhav, "Formulation, Development and Evaluation of Bilayer Tablet of Flurbiprofen", International Journal of Scientific Research in Science and Technology (IJSRST), Online ISSN : 2395-602X, Print ISSN : 2395-6011, Volume 6 Issue 1, pp. 246-251, January-February 2019.

Available at doi :

https://doi.org/10.32628/IJSRST196130 Journal URL : http://ijsrst.com/IJSRST196130 